\title{
OPTIMALISASI SOLAR CELL MENGGUNAKAN UMPAN BALIK LAMPU
}

\author{
Moethia Faridha ${ }^{1}$ \\ Ani meiliani Noor Hafizah ${ }^{2}$ \\ Ayu Novia Lisdawati ${ }^{3}$ \\ Program Studi Teknik Elektr, Universitas Islam Kalimantan MAB ${ }^{123}$ \\ bariethia@gmail.com, animeiliani@gmail.com,noviayu57@gmail.com
}

\begin{abstract}
ABSTRAK
Pembangkit Listrik Tenaga Surya (PLTS) pada saat ini menjadi energi terbarukan alternatif yang paling digemari pada saat ini. PLTS merupakan pembangkit yang menggunakan solar sel atau panel surya untuk mendapatkan energi matahari. Indonesia merupakan daerah khatulistiwa, daerah tropis yang selalu mendapatkan sinar matahari dari jam 06.00-17.00. Tetapi kenyataannya jam efektif solar sel tidak seperti itu hal tersebut, dikarenakan posisi pagi atau senja mempengaruhi penerimaan solar sel begitu pula sudut kemiringan cahaya matahari, kondisi berawan, dan mendung. Bahkan pada saat malam hari solar sel sama sekali tidak mendapatkan energi.

Dalam penelitian ini, peneliti akan memberikan umpan balik cahaya agar pada saat malam hari dari jam 6 sore sampai jam 6 pagi ke solar sel agar mendapatkan energi walaupun bukan jam efektif. Caranya memberikan umpan balik berupa lampu LED, lampu LHE dan lampu pijar. Lampu yang digunakan terlebih dahulu dicari lumen yang hampir mendekati dengan daya $(\mathrm{P})$ yang berbeda. Dari tiga jenis lampu tersebut akan diukur tegangan dan arusnya disisi output inverter.

Tujuan dari penelitian ini mengidentifikasi pengukuran tegangan (v), arus listrik (I), daya listrik (P) dan intensitas cahaya pada solar sel dengan umpan balik lampu LED, LHE dan pijar melalui inverter serta menganalisa pengukuran tegangan (v), arus listrik (I), daya listrik (P) dan intensitas cahaya pada solar sel dengan umpan balik lampu LED, LHE dan pijar melalui inverter

Dari hasil pengukuran lampu LHE, LED dan lampi pijar, Intensitas cahaya tegangan, arus dan daya yang dihasilkan yang sangat berpengaruh terhadap kinerja panel surya adalah lampu LHE dibandingkan lampu LED dan pijarl ini disebabkan karena cahaya lampu LHE lebih fokus terarah sedangkan lampu pijar lebih banyak dikonversi ke panas dibandingkan cahaya. Hasil pengukuran yang didapat untuk tegangan paling besar Dari Lampu LHE 7,30 Volt masih di bawah nilai dari hasil penyinaran matahari sebesar $12 \mathrm{v}$.
\end{abstract}

Kata Kunci : Solar sell, optimalisasi, lhe, led pijar 


\section{PENDAHULUAN}

Pembangkit Listrik Tenaga Surya (PLTS) pada saat ini menjadi energi terbarukan alternatif yang paling digemari pada saat ini. PLTS merupakan pembangkit yang menggunakan solar sel atau panel surya untuk mendapatkan energi matahari. Indonesia merupakan daerah khatulistiwa, daerah tropis yang selalu mendapatkan sinar matahari dari jam 06.00-17.00. Tetapi kenyataannya jam efektif solar sel tidak seperti itu hal tersebut, dikarenakan posisi pagi atau senja mempengaruhi penerimaan solar sel begitu pula sudut kemiringan cahaya matahari, kondisi berawan, dan mendung. Bahkan pada saat malam hari solar sel sama sekali tidak mendapatkan energi.

Dalam penelitian ini, peneliti akan memberikan umpan balik cahaya agar pada saat malam hari dari jam 6 sore sampai jam 6 pagi ke solar sel agar mendapatkan energi walaupun bukan jam efektif. Caranya memberikan umpan balik berupa lampu LED, lampu LHE dan lampu pijar. Lampu yang digunakan terlebih dahulu dicari lumen yang hampir mendekati dengan daya $(\mathrm{P})$ yang berbeda. Dari tiga jenis lampu tersebut akan diukur tegangan dan arusnya disisi output inverter.

Rumusan Masalah dalam penelitian ini adalah bagaimana mengidentifikasi pengukuran tegangan (v), arus listrik (I), daya listrik (P) dan intensitas cahaya pada solar sel dengan umpan balik lampu LED, LHE dan pijar melalui inverter serta bagaimana Analisa pengukuran tegangan (v), arus listrik (I), daya listrik (P) dan intensitas cahaya pada solar sel dengan umpan balik lampu LED, LHE dan pijar melalui inverter.

\section{METODE PENELITIAN}

\section{METODE}

Tahapan Penelitian

1. Lokasi Penelitian : Kampus Universitas Islam Kalimantan

2. Mengumpulkan bahan-bahan yang digunakan pada penelitian :

a. Satu buah Panel sel surya dengan kapasitas 100 Wattpeak (Wp) digunakan untuk mengkonversi cahaya matahari menjadi energi listrik

b. Accumulator $12 \mathrm{~V}, 100 \mathrm{Ah}$

c. Inverter 500 Watt

d. Lampu LED 8 watt (720 lumen), LHE 12 watt (720 lumen) dan Pijar 75 watt (750 lumen).

3. Mengumpulkan alat yang digunakan : Multitester, Lux meter

4. Peubah yang diamati/diukur : tegangan (v), arus (I), daya listrik (P) dan intensitas cahaya

5. Rancangan Penlitian : menggunakan penelitian kuantitatif

6. Teknik Pengumpulan Data 
Perakitan modul sel surya merupakan bagian dari tahapan penelitian ini. Caranya memberikan umpan balik berupa lampu LED, lampu LHE dan lampu pijar. Lampu yang digunakan terlebih dahulu dicari lumen yang hampir mendekati dengan daya (P) yang berbeda. Dari tiga jenis lampu tersebut akan diukur tegangan dan arusnya disisi output inverter.

\section{HASIL DAN PEMBAHASAN}

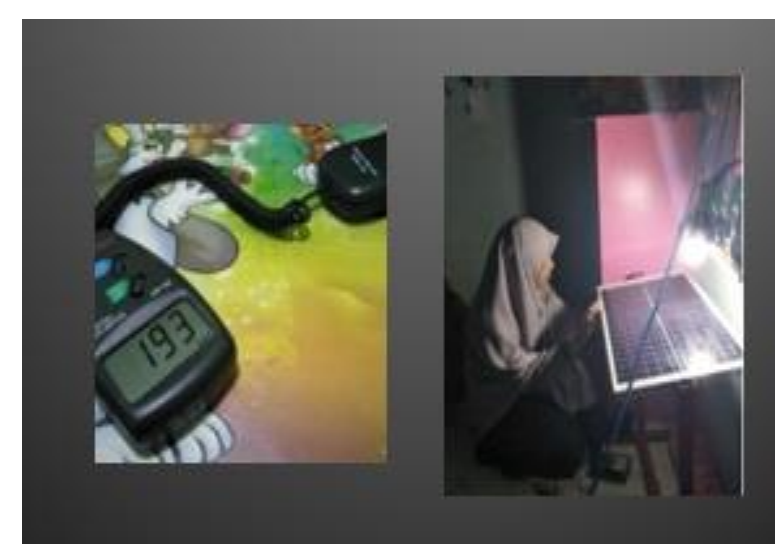

Gambar 1. Pengukuran Lumen menggunakan Lux meter Digital

Tabel 1 Pengukuran Tegangan, Arus, Daya, Intensitas Cahaya

\begin{tabular}{|c|c|c|c|c|c|c|c|c|c|}
\hline \multirow{4}{*}{\multicolumn{2}{|c|}{$\begin{array}{c}\text { Jenis } \\
\text { Lampu }\end{array}$}} & \multicolumn{8}{|c|}{ Waktu } \\
\hline & & \multicolumn{4}{|c|}{\begin{tabular}{|c|}
6 jam \\
\end{tabular}} & \multicolumn{4}{|c|}{$6 \mathrm{jam}$} \\
\hline & & \multirow{2}{*}{$\begin{array}{c}\mathrm{V} \\
\text { (volt) }\end{array}$} & \multirow{2}{*}{$\frac{\mathrm{I}}{(\mathrm{mA})}$} & \multirow{2}{*}{$\frac{P}{\text { (Watt) }}$} & \multirow{2}{*}{\begin{tabular}{|c|} 
Lx \\
(lumen)
\end{tabular}} & \multirow{2}{*}{$\begin{array}{c}\mathrm{V} \\
\text { (volt) }\end{array}$} & I & \multirow{2}{*}{$\frac{P}{\text { (Watt) }}$} & \multirow{2}{*}{$\frac{\mathrm{Lx}}{\text { (lumen) }}$} \\
\hline & & & & & & & $(\mathrm{mA})$ & & \\
\hline \multirow{5}{*}{ LED } & 1 & 7,18 & 19,65 & 0,141 & 7.74 & 7,17 & 19,50 & 0,140 & 7.724 \\
\hline & 2 & 7,15 & 19,75 & 0,141 & 7.742 & 7,14 & 19,51 & 0,139 & 7.14 \\
\hline & 3 & 7,22 & 20,05 & 0,145 & 7.75 & 7,22 & 19,51 & 0,141 & 7.714 \\
\hline & 4 & 7,22 & 20,05 & 0,145 & 7.75 & 7,22 & 19,51 & 0,141 & 7.714 \\
\hline & 5 & 7,17 & 19,75 & 0,141 & 7.635 & 7,16 & 19,43 & 0,139 & 7.519 \\
\hline \multirow{5}{*}{ LHE } & 1 & 7,23 & 31,70 & 0,229 & 10.1 & 7,16 & 30,00 & 0,215 & 10 \\
\hline & 2 & 7,22 & 31,65 & 0,228 & 10.075 & 7,19 & 31,00 & 0,223 & 10.06 \\
\hline & 3 & 7,30 & 33,55 & 0,245 & 10.4 & 7,28 & 33,05 & 0,241 & 10.34 \\
\hline & 4 & 7,18 & 32,68 & 0,234 & 10.356 & 7,20 & 31,24 & 0,224 & 10.1 \\
\hline & 5 & 7,17 & 31,45 & 0,225 & 10.245 & 7,16 & 31,19 & 0,223 & 10.217 \\
\hline \multirow{5}{*}{ Pijar } & 1 & 7,21 & 25,99 & 0,187 & 1.016 & 7,20 & 23,22 & 0,167 & 1.013 \\
\hline & 2 & 7,20 & 25,97 & 0,186 & 1.014 & 7,20 & 25,92 & 0,187 & 1.016 \\
\hline & 3 & 7,22 & 27,67 & 0,199 & 1.07 & 7,19 & 23,04 & 0,166 & 1.011 \\
\hline & 4 & 7,20 & 24,86 & 0,178 & 1.054 & 7,20 & 23,02 & 0,165 & 1.009 \\
\hline & 5 & 7,19 & 23,78 & 0,170 & 1.032 & 7,19 & 22,78 & 0,163 & 1.024 \\
\hline
\end{tabular}


Pada saat pengukuran dengan waktu 6 jam pertama dan 6 jam kedua Intensitas cahaya terbesar dihasilkan lampu LHE (10,36 $\operatorname{lm}$ dan 10,34) dibandingkan LED dan L. Pijar, hal ini disebabkan karena untuk melihat perbandingan panas serta pengujian untuk melihat bagaimana distribusi cahaya lampu LED bila dibandingkan dengan lampu hemat energi. Dan dari hasil yang didapat Lampu LED memiliki panas yang lebih rendah dibandingkan dengan lampu hemat energi. Sementara lampu hemat energi memiliki distribusi cahaya yang lebih baik dibandingkan lampu LED.

\section{KESIMPULAN}

1. Dari hasil pengukuran lampu LHE, LED dan lampi pijar, Intensitas cahaya tegangan, arus dan daya yang dihasilkan yang sangat berpengaruh terhadap kinerja panel surya adalah lampu LHE dibandingkan lampu LED dan pijar ini disebabkan karena cahaya lampu LHE lebih fokus terarah sedangkan lampu pijar lebih banyak dikonversi ke panas dibandingkan cahaya.

2. Hasil pengukuran yang didapat untuk tegangan paling besar Dari Lampu LHE 7,30 Volt masih di bawah nilai dari hasil penyinaran matahari sebesar $12 \mathrm{v}$.

\section{DAFTAR PUSTAKA}

[1] DIFUSI, Volume 1, No.1, Januari 2018 ISSN 2615-2363 Arya Wulung, Purwinda Iriani, Siti Saodah, Sri Utami, Yanti Suprianti

[2] Journal An-nafs: Vol. 1 No. 2 Desember 2016 M. Arif Khoiruddin, Imam Taulabi dan Ali Imron Institut Agama Islam Tribakti Kediri Email: arif.khoiruddin84@gmail.com

[3]Jurnal EECCIS Vol. 6, No. 1, Juni 2012 M. Rif'an, Sholeh HP, Mahfudz Shidiq; Rudy Yuwono;Hadi Suyono dan Fitriana S. 